\title{
External Debt and Economic Growth in Turkey: An Empirical Analysis
}

Tuncer GÖVDELI (https://orcid.org/0000-0002-6600-8684), Department of Economics, Gaziantep University, Turkey; e-mail: tgovdeli@gmail.com

\section{Türkiye'de Dış Borç ve Ekonomik Büyüme: Ampirik Bir Analiz}

\begin{abstract}
This study analyzes the impact of external debt stock, openness and the consumer price index on economic growth, based on time series data obtained from the World Bank for the period from 1970 to 2016. For this report's purpose, the stability of the series was analyzed. Having identified the series to have first degree 1(1) stability, the ARDL bounds testing approach was applied and a relationship of cointegration was established. In light of these findings, it has been observed that external debt has a positive impact on economic growth, while openness and consumer price index have a negative impact. Therefore, this study recommends keeping openness and the consumer price index under control to increase economic growth with the help of external debt.

Keywords $\quad$ : Economic Growth, External Debt, ARDL Bound Test, Turkey.

JEL Classification Codes : O O, H63.

\section{$\ddot{\mathbf{O z}}$}

Bu çalışmada Türkiye'de 1970 ile 2016 dönemi zaman serisi verileri Dünya Bankası'ndan alınarak dış borç stoku, dışa açıklık ve tüketici fiyat endeksinin ekonomik büyümeyle olan etkisi araştırılmıştır. Bu amaçla serilerin durağanlıkları analiz edilmiştir. Serilerin birinci dereceden I(1) durağan oldukları belirlendikten sonra ARDL sınır testi yöntemi kullanılarak eşbütünleşme ilişkisi tespit edilmiştir. Elde edilen bulgular ışığında dış borç ekonomik büyümeyi olumlu etkilemekte, dişa açıklık ve tüketici fiyat endeksi ekonomik büyümeyi negatif yönde etkilemektedir. Bu nedenle çalışma, dışa açıklık ve tüketici fiyat endeksinin kontrol altına alınıp dış borç yardımıyla ekonomik büyümeyi artırılabileceğini tavsiye etmektedir.
\end{abstract}

Anahtar Sözcükler $\quad$ : $\quad$ Ekonomik Büyüme, Dış Borç, ARDL Sınır Testi, Türkiye. 


\section{Introduction}

Sustainable economic growth is a source of concern for all economies. External debt helps achieve a certain level of advantage in the fiscal sphere as well as helping economic growth. However, high fiscal imbalance, inefficient use of resources and re-planning external debt can cause a high external debt stock. Additionally, following insufficient exports, inflexible imports and less capital inflow, external debt is a potential problem for developing economies. Many economies rely on more external debt to be able to enable existing external debt repayments, and this not only causes a higher fiscal deficit but also creates more debt from debt. Many countries decrease their expenditure in an effort to maintain economic discipline, and this impedes economic growth (Shabbir, 2013).

Countries resort to incurring external debt for various reasons such as funding development projects, performing short-term responsibilities, performing long-term responsibilities, access to foreign currency, and purchasing equipment. Regardless of the reason, increasing external debt creates responsibilities for a certain portion of the country. These activities are registered in the country's current and capital accounts. There is no consensus regarding the impact of external debt on growth. Having both positive and negative aspects, external debt is perceived by some experts to have a positive impact on economic growth by means of increasing capital inflow. External debt not only provides capital for industrial development, it also offers the technology, technological expertise and access to foreign markets necessary to mobilize the human and material resources of a country to achieve economic growth. On the other hand, when channeled only into certain sectors, external debt will impede investment and decrease economic growth (Zaman \& Arslan, 2014).

In the thirty-year period after the 1950s, current account deficits came to be perceived as normal. In an effort to maintain and increase economic growth, countries created suitable conditions for foreign investors. For example, despite being a petroleum exporter, Mexico became unable to pay off its debts in 1982, and this made other countries have a more hesitant approach towards foreign debt. Since 1982, the problem of external debt has been of critical significance and started debates on the debt crisis (Were, 2001).

As the debts of developing countries have been increasing over the past years, analyzing the impact of external debt on financing development processes has become increasingly important. In his proposed debt cycle thesis, Avramovic (1964) confirms that external debt is an important funding source for an economy characterized by low domestic savings. According to predictions of the debt cycle, domestic savings should be increased to be able to finance a higher investment proportion in the long term. As external debt stock increases and domestic savings are still low, many developing countries are still trapped in this debt cycle (Drine \& Nabi, 2010).

Due to a shortage of appropriate technology, scarce capital, low savings, low investment and the ensuing slow economic growth, developing countries face many administrative, economic, social and political problems. As a result of all these persistent 
problems, along with a low level of per capita income, the quality of life in developing countries is often low. Along with serious debt crises around the world, unforeseeable economic crises proliferate in both developing and developed countries. Many developing countries sink into poverty due to their increasing and unsustainable debts to creditor countries and to the World Bank International Monetary Fund (IMF) (Azam et al., 2013).

The main objective of this study is to analyze the relationship of openness and consumer price index with economic growth. For this purpose, annual time series data for the period from 1970 to 2016 have been used. The first chapter of the study provides theoretical information as well as information for Turkey. The second chapter consists of a literature review. The third chapter of the study comprises materials, methods and findings. ARDL bounds testing has been used in this study. ADF and PP unit root tests have been adopted to test the stability of series at the $\mathrm{I}(0)$ or $\mathrm{I}(1)$ level, which is a prerequisite for ARDL bounds testing. Having met the prerequisites for ARDL bounds testing, cointegrating coefficients were estimated. Based on the test results, it has been concluded that external debt has a positive impact on economic growth in Turkey, while openness and consumer price index have a negative impact. The last chapter of the study includes conclusions and political recommendations.

\section{External Debt Stock in Turkey}

Before 1976, the debt stock in Turkey stood at a very low level. The external debt stock rose from $\$ 274$ million in 1970 to $\$ 600$ million in 1976 . It can be observed that the debt stock has been increasing since 1976. The external debt stock reached $\$ 4942$ million in 1990 , almost two and a half times more than the $\$ 1913$ million in 1980 . Having reached $\$ 116799$ million in 2000, the external debt stock went down to $\$ 112946$ million in 2001 as a result of the 2001 economic crisis. Reaching \$290571 million in 2008 after the economy recovered from the previous crisis, external debt went down to \$278829 million in 2009 as a result of the 2008 global economic crisis. The external debt stock in Turkey stood at $\$ 405656$ million in 2016. The crises of 1994, 2001 and 2008 caused decreases in our external debt stock (Figure 1).

Figure 2 shows Turkey's external debt stock as percentage of GDP While in 1970 the external debt stock stood at $16.07 \%$ of GDP, it decreased to $11.33 \%$ in 1975 . In certain periods the external debt stock decreased in percentage. The crises in Turkey often caused an increase in the percentage of the external debt stock. While in 1993 the percentage of the external debt stock was $38.07 \%$ of GDP, it rose to $50.69 \%$ after the 1994 crisis. The percentage of the external debt stock rose from $42.78 \%$ of the GDP in 2000 to $56 \%$ in 2001 , reaching a record high in Turkish history. The 2008 crisis created an increase in the external debt stock as percentage of GDP. 
Figure: 1

Turkey's External Debt Stock 1970-2016 (in current US \$, million \$)

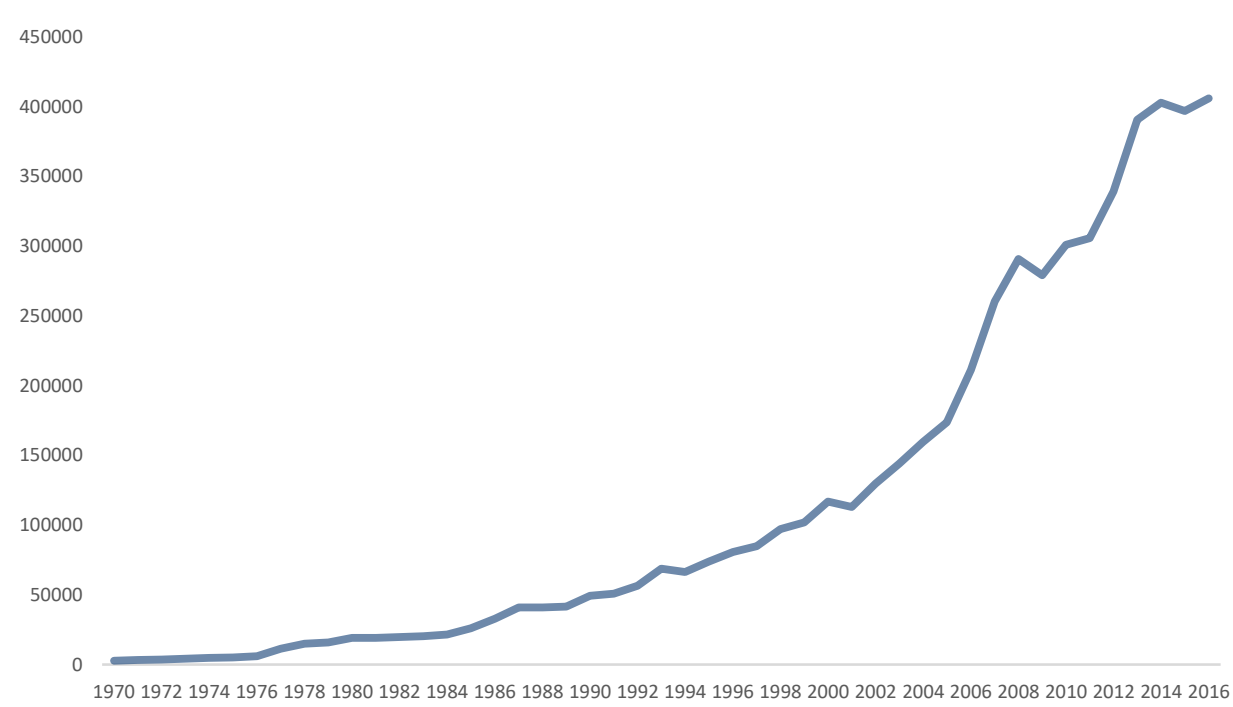

Figure: 2

Turkey's External Debt Stock 1970-2016 (\% GDP)

60

50

40

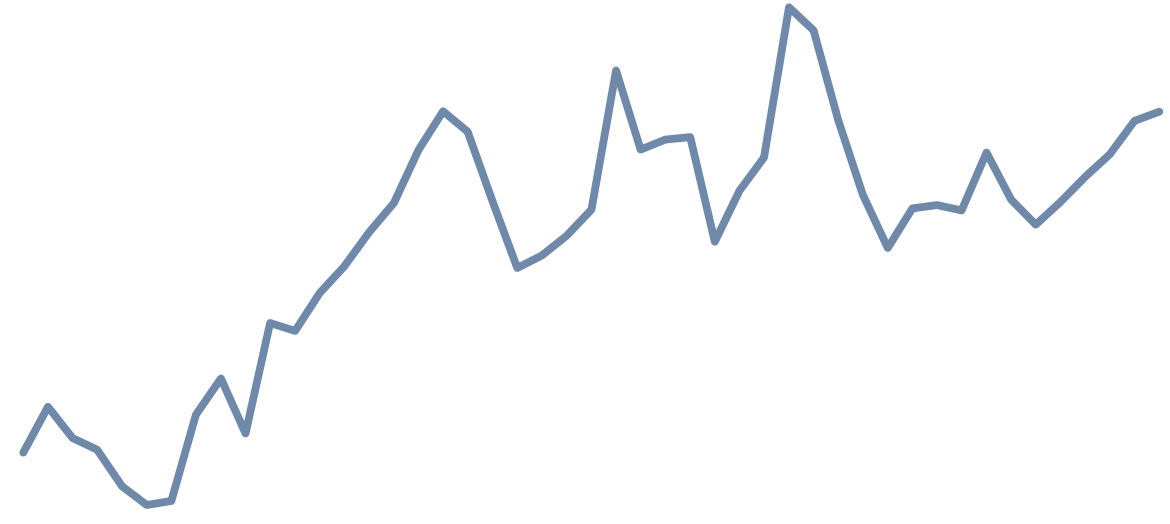

10

197019721974197619781980198219841986198819901992199419961998200020022004200620082010201220142016 
Figure: 3

Economic Growth in Turkey, 1970-2016

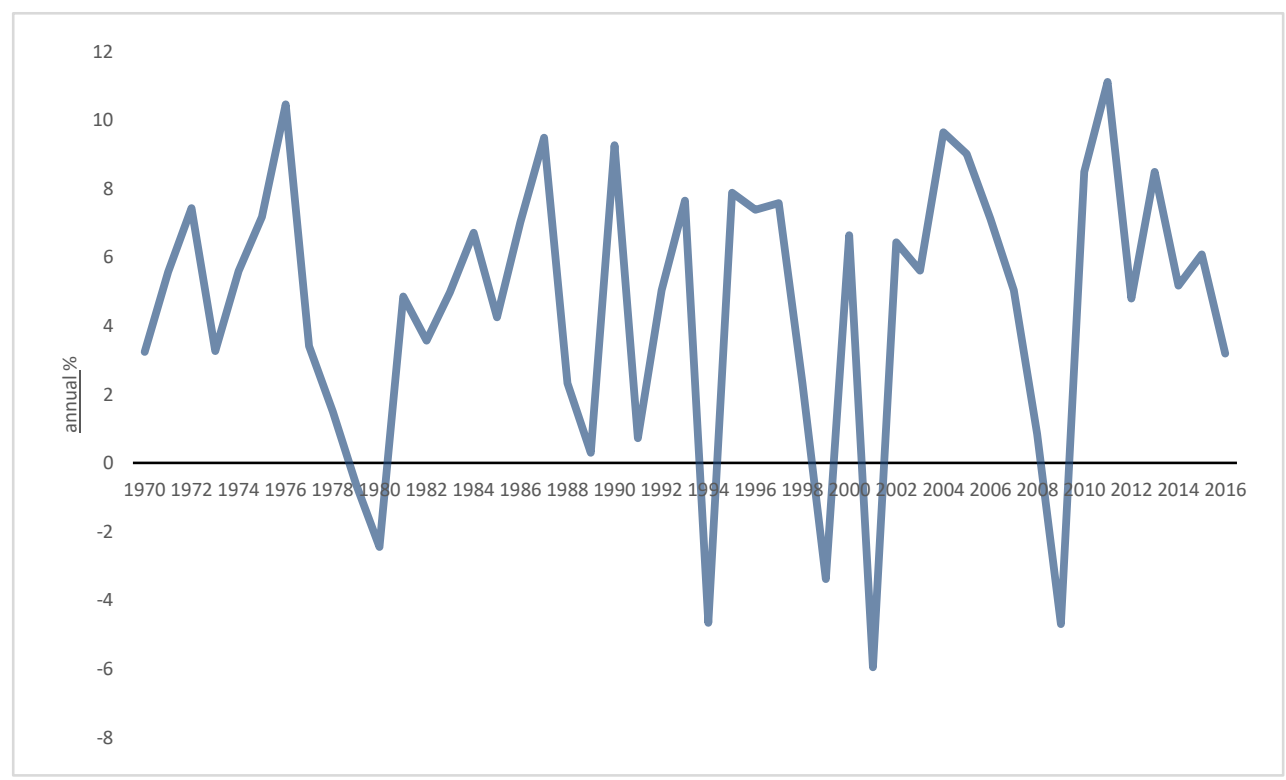

While Turkey's economy grew in the past fifty years, it also experienced serious fluctuations. A small-deficit economy, the Turkish economy is highly sensitive to international fluctuations. The petroleum crises in 1973 and 1978, the 1994 crisis, the 2001 crisis, and the 2008 crisis all had a very negative impact on Turkey's economic growth (Figure 3). Turkey's annual growth will reach quite high levels with better crisis management.

\section{Literature Review}

Findings presented in current the literature differ from one another. While some studies indicate a positive impact of external debt on economic growth, others indicate a negative one. In studies performing causality analyses, the direction of causality may differ.

Studies concluding that external debt has a negative impact on economic growth in Turkey include the one by Bilginoğlu and Aysu (2008), which focused on the period from 1965 to 2005. They reached the conclusion that the external debt overhang in Turkey has caused external debt to have a negative impact on economic growth. Focusing on the period from 1980 to 2009, Çöğürcü and Çoban (2011) studied the impact external debt has on economic growth. Based on their findings, external debt has a negative impact on economic growth. Çiçek et al. (2010) analyzed the relationship between external and internal debt and economic growth. Based on data concerning the period between 1990-2009, the study concluded that, while internal debt has a positive impact on economic growth, external debt 
had a negative one. İpek and Yaşar (2008) studied the impact of external debt on economic growth for the period from 1989 to 2007, using cointegration and causality analyses. They proved a cointegration and bidirectional causality relationship between external and economic growth. Uysal et al. (2009) studied the relationship between external debt and economic growth for the period from 1965 to 2007 . They proved external debt has a negative impact on economic growth. Çelik and Direkçi (2013) analyzed the relationship between external debt and economic growth in Turkey for the period of 1991 to 2010. Based on their findings, they established that external debt has a negative impact on economic growth.

Studies concluding that external debt has a positive impact on economic growth in Turkey include Umutlu et al. (2011), who analyzed the relationship between tax revenues, debt (both internal and external), and economic growth for the period from 1990 to 2008. Their conclusion is that external debt has a positive impact on economic growth. Based on quarterly data, Korkmaz (2015) analyzed the relationship between external debt and economic growth for the period from 2003 to 2014. There is a unidirectional causality relationship from external debt to economic growth, and external debt has a positive impact on economic growth for a certain amount of time.

Studies concluding that external debt has a negative impact on economic growth around the world include Calderón and Fuentes (2013), whose study focused on Latin American countries and showed the negative impact of external debt on economic growth for the period from 1970 to 2010. Another study focusing on Kenya, using the regression analysis method concluded that external debt had a negative impact on economic growth for the period from 1970 to 1995 (Were, 2001). Kharusi and Ada (2018) analyzed the impact of external debt on Oman's economy for the period from 1990 to 2015. Based on their findings, they established that external debt has a negative impact on economic growth in Oman. In their study focusing on Iran, Safdari and Mehrizi (2011) studied the period from 1974 to 2007. Their findings show that openness has a negative impact on economic growth.

Studies focusing on world economies where external debt has a negative impact on economic growth include Amoateng and Amoako (1996), whose work analyze the relationship between external debt and economic growth in 35 African countries. Their findings show that there is a unidirectional and positive causality relationship between economic growth and external debt. Sulaiman and Azeez (2012) studied the impact of external debt on economic growth in Nigeria from 1970 to 2010. Their findings show that openness has a positive impact on economic growth. Frimpong and Oteng-Abayie (2006) analyzed the economy of Ghana between 1970 and 1999. They identified a positive relationship between external debt and economic growth. In their study focusing on six Pacific island countries, Jayaraman and Lau (2009) study the period from 1988 to 2004. Jayaraman and Lau (2009) concluded that there is a positive relationship between external debt and economic growth. 


\section{Data Set and Method}

In this study, gross domestic product (GDP) data has been calculated (in current US $\$$ ) as an indicator of growth, using the following formula: external debt stock (DS) data (in current US \$), data on openness [(Import+Export)/(GDP)]. Import, export and GDP data was used here (in current US \$). The consumer price index has been calculated according to the percentage it changes annually. All the data used here are annual time series, concerning the years 1970 to 2016, and was obtained from the World Bank database.

\subsection{Unit Root Test Analysis}

A prerequisite for the ARDL bounds testing is that the series stand at levels $\mathrm{I}(0)$ or I(1). If the variables used in the ARDL model are stationary at level I(2), the model will not function properly and the resulting findings will likely be wrong. The Phillips and Perron (PP) and Augmented Dickey Fuller (ADF) tests were adopted to analyze the stability of the GDP, BS, OP and CPI variables.

Table: 1

Unit Root Test Results

\begin{tabular}{|c|c|c|c|c|c|}
\hline Variables & $\begin{array}{l}\text { LEVEL } \\
\text { ADF } \\
\text { t statistics }\end{array}$ & $\begin{array}{l}\text { PP } \\
\text { t statistics }\end{array}$ & $\begin{array}{l}1^{\mathrm{ST}} \text { DIFFEF } \\
\text { ADF } \\
\mathbf{t} \text { statistics }\end{array}$ & $\begin{array}{l}\text { PP } \\
\text { t statistics }\end{array}$ & Result \\
\hline GDP & $-1,366$ & $-1,377$ & $-6,785^{*}$ & $-6,790^{*}$ & $\mathrm{I}(1)$ \\
\hline BS & $-2,507$ & $-2,624$ & $-5,175^{*}$ & $-5,175^{*}$ & $\mathrm{I}(1)$ \\
\hline OP & $-2,033$ & $-2,030$ & $-5,798 *$ & $-5,764 *$ & $\mathrm{I}(1)$ \\
\hline CPI & $-1,413$ & $-1,413$ & $-7,424 *$ & $-7,378^{*}$ & $\mathrm{I}(1)$ \\
\hline
\end{tabular}

Note: Critical values $1 \%$ and $5 \%$ are represented by $*$ and $* *$, respectively.

The results of the ADF and PP unit root tests are given in Table 1. Based on the test results, the variables have unit roots both stationary and at stationary-trend levels. It is observed that the series become stationary when the difference is taken $\mathrm{I}(1)$. Based on the resulting findings, the prerequisite for the ARDL bounds testing has been met.

\subsection{Cointegration Analysis}

The objective of the study is to analyze the long-term relationship external debt stock, openness and consumer price index with economic growth. The Autoregressive Distributed Lag (ARDL) model, developed by Peseran et al. (2001), has been adopted for this study. Compared to the Johansen cointegration test, developed by Johansen and Juselius (1990), the ARDL bounds test yields more desirable effects and therefore is used commonly for empirical modeling. This model has four advantages: i) it yields better results for small samplings (Ghatak \& Siddiki, 2001). ii) The ARDL approach can be used for the series which are stationary at level zero I(0) as well as at level one I(1). The Johansen cointegration test does not allow such an operation. iii) The ARDL approach deals with the endogeneity of certain variable regressions by providing long-term estimates and significant t-statistics (Odhiambo, 2009). iv) The ARDL approach also enables the simultaneous identification of the short and long-term effects of a variable (Bentzen \& Engster, 2001). 
The fact that the stability of variable stands at I(1) shows that the ARDL model is suitable for use. An adapted version of the Peseran et al. (2001) model for the purposes of our study is provided below:

$$
\begin{aligned}
& \Delta G D P=\alpha_{0}+\sum_{i=1}^{m} \alpha_{1 i} \Delta G D P_{t-1}+\sum_{i=1}^{m} \alpha_{2 i} \Delta B S_{t-1}+\sum_{i=1}^{m} \alpha_{3 i} \Delta O P_{t-1}+ \\
& \sum_{i=1}^{m} \alpha_{4 i} \Delta C P I_{t-1}+\gamma_{1} G D P_{t-1}+\gamma_{2} B S_{t-1}+\gamma_{3} O P_{t-1}+\gamma_{4} C P I_{t-1}+\varepsilon_{t}
\end{aligned}
$$

Here, $\Delta$ represents first-level difference, $\alpha$ represents the parameters to be estimated, et represents white noise error term. The ARDL approach estimates the optimum duration of delay for each variable. The empty hypotheses which does not display bounds test cointegration are decided based either on F statistics or Wald statistics.

The empty hypotheses which do not have cointegration between the variable are shown in equation 1 as $H_{0}: \gamma_{1}=\gamma_{2}=\gamma_{3}=\gamma_{4}=0$ and the alternative hypothesis as $H_{1}: \gamma_{1} \neq \gamma_{2} \neq \gamma_{3} \neq \gamma_{4} \neq 0$.

Table: 2

Diagnostic Test Results

\begin{tabular}{|l|l|l|}
\hline Selected Model & \multicolumn{2}{|c|}{$(3,1,0,2)$} \\
\hline $\mathrm{k}$ & \multicolumn{2}{|c|}{3} \\
\hline F statistic & $\mathrm{I}(0)$ Bound & 4,19 \\
\hline Critical Values & 3,65 & $\mathrm{I}(1)$ Bound \\
$\% 1$ & 2,79 & 4,66 \\
$\% 5$ & 2,37 & 3,67 \\
$\% 10$ & \multicolumn{1}{|c|}{ Diagnostic Tests } \\
\hline \multicolumn{2}{|c|}{3,20} \\
\hline $\mathrm{R}^{2}$ & \multicolumn{2}{|c|}{0,991} \\
\hline Adjusted R & \multicolumn{2}{|c|}{0,989} \\
\hline F statistics & 441.398 \\
\hline LM Test & 0,859 \\
\hline ARCH Test & 0,766 \\
\hline RESET Test & 0,876 \\
\hline Normality Test & 0,586 \\
\hline
\end{tabular}

The diagnostic test results of the ARDL model are given in Table 2. The F statistics for the ARDL model is 4.19, which exceeds the upper limit (3.67) when analyzed at meaning level 5\%. Therefore there is a cointegration in the ARDL model. Based on evaluations of diagnostic tests, the LM test (Breusch-Godfrey Lagrange Multiplier) tests whether there is an autocorrelation in the model. The main hypothesis that there is an autocorrelation $\mathrm{H}_{0}$ has been rejected on the basis of the test result. Therefore, it was established whether the model had a problem of autocorrelation or not. The ARCH test is used to test the problem of changing variance. The results of the ARCH test show that there is not a problem of changing variance. The Ramsey RESET test is used to analyze whether or not the ARDL model has been installed with the correct specifications. Based on the results of the RESET test, it can be observed that the estimation result is significant. The Jarque-Bera Normality test is used to analyze whether the distribution of error terms is normal. The results of the test reveal that the error term of the model is distributed normally. 
Table: 3

\section{Long-term Estimates}

\begin{tabular}{llllll}
\hline & ARDL Estimate & & FMOLS Estimate & & \multicolumn{2}{c}{ DOLS Estimate } \\
& Coefficients & p-value & Coefficients & p-value & Coefficients \\
\cline { 2 - 6 } BS & $0,813^{*}$ & 0,000 & $0,898^{*}$ & 0,000 & $0,910^{*}$ \\
OP & $-0,398^{* *}$ & 0,033 & $-0,489^{*}$ & 0,002 & $-0,633^{* *}$ \\
CPI & $-0,171^{*}$ & 0,001 & $-0,141^{*}$ & 0,001 & $-0,154^{*}$ \\
C & $5,983^{*}$ & 0,003 & $3,526^{* *}$ & 0,024 & 3,224 \\
\hline
\end{tabular}

Note: Critical values $1 \%$ and $5 \%$ are represented by $*$ and $* *$, respectively.

Long term estimates are given in Table 3 based on three distinct methods. The results of the FMOLS and DOLS tests are included in addition to the ARDL test in an effort to increase the reliability of obtained coefficients. Based on the results, there is a positive relationship between external debt stock and economic growth, and the variable that is statistically significant at a level of $1 \%$ is in compliance with the existing literature. It can be observed that there is a negative relationship between openness and economic growth in the long term. The fact that the coefficient estimation of the three models is significant at a level of 5\% shows that openness is an important variable in economic growth. The relationship between economic growth and consumer price index is statistically significant at a level of $1 \%$. As expected, the elasticity coefficient is observed to be negative. The consumer price index has a negative impact on economic growth in the long term.

Table: 4

Short-term Estimates

\begin{tabular}{lll}
\hline & Coefficients & p-value \\
\cline { 2 - 3 } D(BS) & $0,528^{*}$ & 0,000 \\
D(OP) & $-0,617^{*}$ & 0,000 \\
D(CPI) & $-0,111^{* *}$ & 0,024 \\
ECT(-1) & $-0,481^{*}$ & 0,000 \\
\hline
\end{tabular}

Note: Critical values $1 \%$ and $5 \%$ are represented by $*$ and $* *$, respectively.

Short-term coefficient estimations are given in Table 4. The elasticity coefficient in the external debt stock is positive in the short term. It can therefore be concluded that external debt has a positive impact on economic growth in the short term. It can also be observed that the openness elasticity coefficient is negative in the short term and has a negative impact on economic growth. As expected, there is a negative relationship between consumer price index and economic growth, and the elasticity coefficient is significant at a level of 5\%. The error correction coefficient is negative and statistically significant. It has been observed that all variables are in accordance with long-term coefficients. $48.1 \%$ of the short-term deviation is corrected in the following term.

Cumulative sum (CUSUM) and cumulative sum of squares (CUSUMQ) charts are given in Figure 4. Parameter determination is established with the help of CUSUM and CUSUMQ Charts. As can be seen in the CUSUM and CUSUMQ charts, it has been established that the estimated parameters remain at 5\% within line limits and are therefore determined. 


\section{Figure: 4 \\ CUSUM and CUSUMQ Charts}
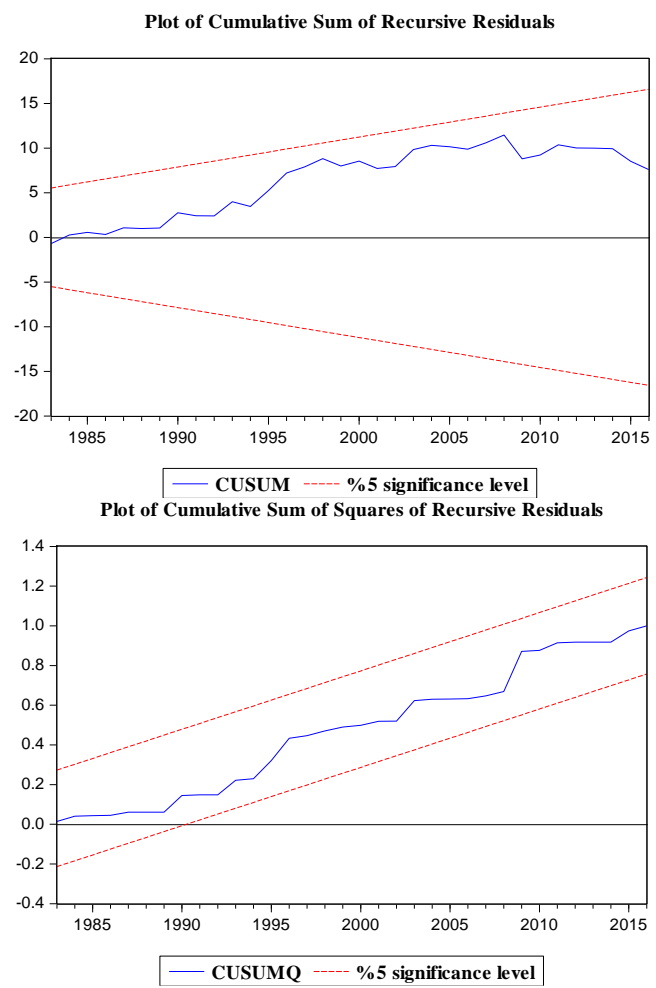

\section{Discussion and Conclusion}

The long-term as well as the short-term relationship between the external debt stock and economic growth in Turkey has been analyzed in this study for the period of 1970-2016. The impact of openness and consumer price index changes on economic growth have also been studied. All the data has been obtained from the World Bank database. While GDP as the economic growth series has been used as the dependent variable, external debt stock, openness and the consumer price index have been used as independent variables. A prerequisite for the ARDL bounds testing is that the series stand stationary at levels zero I $(0)$ or one I(1). For this purpose, ADF and PP unit root tests were used to determine the stability of the series. It was established that all the series that were used were stationary at level I(1). The fact that the variable are I(1) stationary means that they meet the prerequisite for the ARDL bounds test. The FMOLS and DOLS methods were used in addition to the ARDL bounds test to estimate the long-term elasticity coefficients of the series.

The long and short-term impacts of external debt stock, openness and consumer price index on GDP were analyzed with the help of the ARDL bounds test. The results obtained 
for the short and the long term are similar. While the elasticity coefficient of the external debt stock is positive, the elasticity coefficients of openness and consumer price index were negative.

The most important finding of this study is that external debt stock increases GDP in the short and the long term, while at the same time openness and consumer price index decrease GDP. Therefore, it cannot be stated that external debt will always necessarily increase economic growth. According to the debt overhang hypothesis, as external debt increases, paying back the debt eventually becomes unsustainable and the country will face crisis after a certain threshold is reached. With a shrinking economy, the country becomes unable to use its resources and may reach an impasse. For this reason, in order to avoid experiencing debt overhang, Turkey must not base its economic growth on external debt but rather on an efficient use of its own resources and funding.

As a result of scarcity of resources within a country, external debt has become an important component of capital for many economies. Even though external debt has a significant impact on economic growth, efficient planning is crucial. For it is necessary to use each debt efficiently and channel it into investments with high added value. A country that becomes too accustomed to taking on external debt may become unable to pay back its debt over time, and this could create a difficult situation for the country. In order to avoid this, external debt must be used as efficiently as possible, and it must be channeled into areas where domestic investment will not be hindered.

\section{References}

Amoateng, K. \& B. Amoako-Adu (1996), "Economic Growth, Export and External Debt Causality: The Case of African Countries", Applied Economics, 28(1), 21-27.

Avramovic, D. (1964), Economic Growth and External Debt, Baltimore The Johns Hopkins Press.

Azam, M. \& C. Emirullah \& A.Q. Khan \& A.C. Prabharker (2013), "The Role of External Debt in Economic Growth of Indonesia - A Blessing or Burden”, World Applied Science Journal, 25(8), 1150-1157.

Bentzen, J. \& T. Engsted (2001), “A Revival of the Autoregressive Distributed Lag Model in Estimating Energy Demand Relationships”, Energy, 26(1), 45-55.

Bilginoğlu, M.A. \& A. Aysu (2008), "Dış Borçların Ekonomik Büyüme Üzerindeki Etkisi: Türkiye Örneği”, Erciyes Üniversitesi İktisadi ve İdari Bilimler Fakültesi Dergisi, (31), 1-23.

Calderón, C. \& J.R. Fuentes (2013), Government debt and economic growth, Inter-American Development Bank.

Çelik, S. \& T. Başkonuş-Direkci (2013), “Türkiye'de 2001 Krizi Öncesi ve Sonrasi Dönemler İçin Dış Borç Ekonomik Büyüme İlişkisi (1991-2010)”, Electronic Turkish Studies, 8(3), 111-135.

Çiçek, H. \& S. Gözegir \& E. Çevik (2010), "Bir Maliye Politikası Aracı Olarak Borçlanma ve Ekonomik Büyüme İlişkisi: Türkiye Örneği (1990-2009)”, Cumhuriyet Üniversitesi Íktisadi ve İdari Bilimler Dergisi, 11(1), 141-156.

Çögürcü, İ. \& O. Çoban (2011), “Dış Borç Ekonomik Büyüme İlişkisi: Türkiye Örneği (19802009)”, KMÜ Sosyal ve Ekonomik Araştırmalar Dergisi, 13(21), 133-149. 
Drine, I. \& M.S. Nabi (2010), "Public External Debt, Informality and Production Efficiency in Developing Countries", Economic Modelling, 27(2), 487-495.

Frimpong, J.M. \& E.F. Oteng-Abayie (2006), "The Impact of External Debt on Economic Growth in Ghana: A Cointegration Analysis", Journal of Science and Technology (Ghana), 26(3), 122-131.

Ghatak, S. \& J.U. Siddiki (2001), "The Use of the ARDL Approach in Estimating Virtual Exchange Rates in India", Journal of Applied Statistics, 28(5), 573-583.

İpek, E. \& B.K. Yaşar (2008), “Türkiye'de Ekonomik Büyüme ve Dış Borç İlişkisi”, Uluslararası Sermaye Hareketleri ve Gelişmekte Olan Piyasalar Uluslararası Sempozyumu, Balıkesir.

Jayaraman, T.K. \& E. Lau (2009), "Does External Debt Lead to Economic Growth in Pacific Island Countries", Journal of Policy Modelling, 31, 272-288.

Kharusi, S.A. \& M.S. Ada (2018), "External Debt and Economic Growth: The Case of Emerging Economy", Journal of Economic Integration, 33(1), 1141-1157.

Korkmaz, S. (2015), "The Relationship between External Debt and Economic Growth in Turkey”, Proceedings of the Second European Academic Research Conference on Global Business, Economics, Finance and Banking, Zurich-Switzerland, Paper ID: Z581, 3-5.

Odhiambo, N.M. (2009), "Energy Consumption and Economic Growth Nexus in Tanzania: An ARDL Bounds Testing Approach", Energy Policy, 37(2), 617-622.

Pesaran, M.H. \& Y. Shin \& R.J. Smith (2001), "Bounds Testing Approaches to the Analysis of Level Relationships", Journal of Applied Econometrics, 16(3), 289-326.

Phillips, P.C. \& P. Perron (1988), “Testing for a Unit Root in Time Series Regression”, Biometrika, 75(2), 335-346.

Shabbir, S. (2013), "Does External Debt Affect Economic Growth: Evidence from Developing Countries", SBP Working Paper Series. No. 63. <http://www.sbp.org.pk/publications/wpapers/2013/wp63.pdf.>, 22.12.2017.

Sulaiman, L.A. \& B.A. Azeez (2012), "Effect of External Debt on Economic Growth of Nigeria", Journal of Economics and Sustainable Development, 3(8), 71-79.

Umutlu, H. \& N. Alizadeh \& A.Y. Erkılıç (2011), "Maliye Politikası Araçlarından Borçlanma ve Vergilerin Ekonomik Büyümeye Etkileri”, Uludă̆ Üniversitesi İktisadi ve İdari Bilimler Fakültesi Dergisi, 30(1), 75-93.

Uysal, D. \& H. Özer \& M. Mucuk (2009), "Dış Borçlanma ve Ekonomik Büyüme İlişkisi: Türkiye Örneği (1965-2007)”, Atatürk Üniversitesi İktisadi ve İdari Bilimler Dergisi, 23(4), 161 178.

Were, M. (2001), "The impact of external debt on economic growth in Kenya: An empirical assessment", Discussion Paper 116, World Institute for Development Economics Research (WIDER), United Nations University.

Zaman, R. \& M. Arslan (2014), "The Role of External Debt on Economic Growth: Evidence from Pakistan Economy", Journal of Economics and Sustainable Development, 5(24), 140147. 